\title{
Sosialisasi Perlindungan Konsumen dalam Islam di Desa Nusa Makmur Kecamatan Air Kumbang
}

\section{Choirunnisak}

Program Studi Perbankan Syariah STEBIS IGM Palembang

Email: choirunnisak-umar@stebisigm.ac.id

\begin{abstract}
This community service activity discusses the introduction of the history of consumer protection in Islam, the argument for consumer protection, consumer rights, and consumer obligations. The purpose of this community service activity is to provide an introduction to consumer protection for recitation scholars in the village of Nusa Makmur. With the hope that participants can understand the rights and obligations of consumers and consumer protection.
\end{abstract}

Keywords: Socialization, Consumer Protection, Islam, Indonesia

\begin{abstract}
Abstrak
Kegiatan pengabdian masyarkat ini membahas tentang pengenalan sejarah perlindungan konsumen dalam Islam, dalil perlindungan konsuman, hak konsumen, kewajiban konsumen. Tujuan kegiatan pengabdian masyarakat ini memberikan pengenalan tentang perlindungan konsumen terhadap ibi-ibi pengajian di desa Nusa Makmur. Dengan harapan peserta bias memahami hak dan kewajiban konsumen serta perlindungan konsumen
\end{abstract}

Kata Kunci: Sosialisasi, Perlindungan Konsumen, Islam, Indonesia

\section{Pendahuluan}

Perlindungan konsumen adalah: "Segala upaya yang menjamin adanya kepastian hukum untuk memberi perlindungan kepada konsumen." (UU.No. 8. 2015)

Perlindungan konsumen yang dijamin oleh Undang-Undang Nomor 8 Tahun 1999 tentang Perlindungan Konsumen adalah adanya kepastian hukum terhadap segala perolehan kebutuhan konsumen. Kepastian hukum itu meliputi segala upaya berdasarkan hukum untuk memberdayakan konsumen memperoleh atau menentukan pilhannya atas barang dan/jasa kebutuhan serta mempertahankan atau membela hak- haknya apabila dirugikan oleh perilaku-perilaku usaha sebagai penyedia kebutuhan konsumen. Hukum perlindungan konsumen secara umum bertujuan memberikan perlindungan bagi konsumen baik dalam bidang hukum privat maupun bidang hukum publik. Kedudukan hukum perlindungan konsumen berada dalam kajian hukum ekonomi. Perlindungan hukum bagi konsumen ini memiliki dimensi banyak, dimana salah satunya adalah perlindungan hukum yang apabila dipandang baik secara materil maupun formal akan semakin terasa sangat penting, dengan demikian upaya-upaya untuk memberikan perlindungan hukum terhadap kepentingan bagi para konsumen merupakan salah satu hal yang penting 
serta mendesak untuk dapat sesegera mungkin dicari solusi dan penyelesaian masalahnya.(Wuria. 2015:5)

Dengan pemahaman bahwa perlindungan konsumen mempersoalkan perlindungan (hukum) yang diberikan kepada konsumen dalam usahanya untuk memperoleh barang dan jasa dari kemungkinan timbulnya kerugian karena penggunaannya, maka hukum perlindungan konsumen dapat dikatakan sebagai hukum yang mengatur tentang pemberian perlindungan kepada konsumen dalam rangka pemenuhan kebutuhannya sebagai konsumen. Dengan demikian, hukum perlindungan konsumen mengatur hak dan kewajiban produsen, serta cara-cara mempertahankan hak dan kewajiban itu. ( Sidabolok. 2010:45).

\section{Metode pengabdian}

\section{Metode pelaksanaan}

Rangkaian kegiatan pengabdian masyarakat adalah sebagai berikut:

1) Bentuk kegiatan

Bentuk kegiatan yang dilakukan dalam sosialisasi tersebut adalah:

$>$ Pemaparan materi tentang perlindungan konsumen dalam ekonomi Islam

$>$ Pemahaman dan Tanya jawab tentang perlindungan konsumen dalam ekonomi Islam.

2) Tempat kegiatan

Adapun tempat kegiatan atau lokasi kegiatan di laksanakan di lapangan desa Nusa Makmur.

3) Proses Kegiatan

Adapun proses kegiatan di laksanakan 2 hari pada hari senin dan hari selasa pada tanggal 12-13 Oktober 2020 . adapun kegiatan yang dilakukan selama kegiatan tersebut adalah sebagai berikut;

a. Pada tanggal 12 oktober 2020:

Adapun kegiatan yang dilakukan pada pertemuan ke -1 adalah sebagai berikut:

1). Registrasi peserta

2). Penyampaian materi sesi 1 oleh Choirunnisak, S.E.I,. M.E. dengan judul sejarah perlindungan konsumen dalam Islam .

3). Penjelasan dalil tentang perlindungan konsumen oleh Mustikawati SE., M.Si.

b. Pada tanggal 13 oktober 2020

Dilaksanakan pada pertemuan ke-2 adalah sebagai berikut:

1). Menyampaikan materisesi II dilakukan oleh Choirunnisak S.E.I., M.E. dengan judul materi perlindungan konsumen di Indonesia.

2). Penjelasan UU perlindungan konsumen di Indonesia oleh Mustikawati S.E., M.Si.

3). Tanya jawab perlindungan konsumen dalam Islam

4). Doa hdan penutup yang di bawakan oleh Choirunnisak, S.E.I., M.E.

\section{Waktu kegiatan dan materi pokok dalam kegiatan}

Pelaksanaan kegiatan dilakukan dalam waktu dua hari pada hari senin dan selasa. Adapun jadwal pelaksanaannya adalah sebagai berikut:

Tanggal 12 Oktober 2020

\begin{tabular}{|l|l|l|}
\hline Waktu & Materi & Narasumber \\
\hline $09.00-09.30$ & Registrasi peserta & Widiyanti \\
\hline $09.30-10.00$ & Pembukaan & Widiyanti \\
\hline $10.00-11.00$ & Materi : & Choirunnisak S.E.I., M.E. \\
\hline
\end{tabular}




\begin{tabular}{|l|l|l|}
\hline & $\begin{array}{l}\text {-sejarah perlindungan } \\
\text { konsumen dalam Islam }\end{array}$ & \\
\hline $11.00-12.00$ & -Dalil perlindungan konsumen & -Mustikawati SE., M.Si. \\
\hline $12.00-13.00$ & ISOMA & ISOMA \\
\hline $13.00-15.00$ & Hak Konsumen & Choirunnisak, S.E.I.,M.E. \\
\hline $14.00-15.00$ & Kewajiban Konsumen & Mustikawati SE. M.Si \\
\hline
\end{tabular}

Tanggal 13 Oktober 2020

\begin{tabular}{|l|l|l|}
\hline Waktu & Materi & Narasumber \\
\hline 09.00-10.30 & $\begin{array}{l}\text { Kewajiban konsumen dalam } \\
\text { hukum Islam }\end{array}$ & Choirunnisak S.E.I., M.E. \\
\hline $\mathbf{1 0 . 3 0 - 1 2 . 0 0}$ & $\begin{array}{l}\text { Hak konsumen dalam } \\
\text { hukum Islam }\end{array}$ & Mustikawati SE.MS.i \\
\hline $\mathbf{1 2 . 0 0 - 1 3 . 0 0}$ & Isoma & Mustikawati SE.M.Si \\
\hline $\mathbf{1 3 . 0 0 - 1 4 . 0 0}$ & Tanya jawab & Choirunnisak S.E.I.,M.E. \\
\hline $\mathbf{1 4 . 0 0 - 1 5 . 0 0}$ & Doa dan penutup & \multicolumn{2}{|l}{} \\
\hline
\end{tabular}

Total durasi pelaksanaan pengabdian pada masyarakat untuk masing-masing pelaksanaan adalah:

\begin{tabular}{|l|l|l|l|l|}
\hline NO & NAMA & NIDN/NPM & Status & Durasi \\
\hline 1 & $\begin{array}{l}\text { Choirunnisak S.E.I., } \\
\text { M.E }\end{array}$ & $\mathbf{2 1 0 9 0 2 9 1 0 3}$ & $\begin{array}{l}\text { Dosen Perbankan } \\
\text { Syariah }\end{array}$ & $\mathbf{3 6}$ jam \\
\hline 2 & Mustikawati SE.M.Si & - & $\begin{array}{l}\text { Dosen Ekonomi } \\
\text { Syariah }\end{array}$ & $\mathbf{3 6}$ jam \\
\hline 3 & Widiyanti & Mahasiswa & 1 jam \\
\hline
\end{tabular}

\section{Hasil dan Pembahasan}

\section{Materi Sosialisasi}

\section{a. Landasan Hukum Perlindungan Konsumen}

1). Landasan Hukum Perlindungan Konsumen Dalam Hukum Islam

Sumber hukum dalam Islam yang telah disepakati oleh para fuqaha ada 4, yaitu berdasarkan Al-Qur'an, Sunnah, Ijma', dan Qiyas. Sumber-sumber hukum ini dijadikan sebagai acuan dalam pengambilan hukum perlindungan konsumen dalam Islam. Al- Qur'an merupakan sumber hukum pertama (sumber primer) dalam ajaran Islam. Sun- nah adalah sumber hukum kedua (sumber sekunder) setelah Al-quran, dan dapat di- jadikan sumber hukum pertama (sumber primer) apabila tidak ditemukan penjelasan atas suatu masalah di dalam Al-Qur'an.

Adapun ijma' adalah kesepakatan semua mujtahid dari kalangan umat Islam pada suatu masa, setelah wafatnya Rasulullah SAW atas suatu hukum syara' mengenai suatu kejadian maupun kasus.( Yahya ddk. 1986. 58-59)

Ijma' han- ya ditetapkan setelah wafatnya Rasulullah SAW dan hanya dapat dijadikan sebagai sumber hukum apabila tidak ditemukan penjelasan atau normanorma hukum di dalam Al-Qur'an maupun sunnah mengenai suatu masalah atau kasus. Sedangkan qiyas adalah menghubungkan suatu kejadi- an yang tidak ada nash-nya kepada kejadian yang ada nash-nya, dalam hukum yang telah ditetapkan oleh nash .(Yahya ddk. 1986. 58-59). Qiyas ini merupakan metode dalam 
pengambilan hukum yang didasarkan pada illat-illat hukum yang ter- kandung di dalamnya.

\section{2). Landasan Hukum Perlindungan Konsumen Di Indonesia}

Di Indonesia yang menjadi sumber hukum perlindungan konsumen adalah Undang-Undang Nomor 8 Tahun 1999 tentang Perlindungan Konsumen yang selanjutnya disingkat UUPK. Undang-undang ini diundangkan pada tanggal 20 April 1999 dan dinyatakan berlaku efektif pada tanggal 20 April 2000 (Sidabolok. 2010:48). UUPK bukanlah satu-sa- tunya UU yang mengatur tentang perlindungan konsumen, tetapi sebagaimana dise- butkan dalam penjelasan umumnya bahwa sebelum UUPK disahkan sebagai undang- undang perlindungan konsumen telah ada 20 UU yang materinya memuat perlindun- gan konsumen sehingga UUPK dijadikan sebagai payung hukum bagi peraturan pe-rundang-undangan lain yang menyangkut konsumen, dan sekaligus mengintegrasi- kannya sehingga dapat memperkuat pen- egakan hukum di bidang perlindungan kon- sumen. UUPK bukan merupakan awal dan akhir dari hukum yang mengatur tentang perlindungan konsumen, tetapi terbuka ke- mungkinan terbentuknya undang-undang baru yang pada dasarnya memuat ketentu- an-ketentuan yang melindungi konsumen (Lihat penjelaasan umum UUKP)

\section{b. Asas dan Tujuan Perlindungan Konsumen}

\section{1). Asas Perlindungan Konsumen Dalam Hu- kum Islam dan UUPK}

Untuk melindungi kepentingan para pi- hak di dalam lalulintas perdagangan/ berbisnis, hukum Islam menetapkan beberapa asas yang dijadikan sebagai pedoman dalam melakukan transaksi, yaitu at-tauhid, is-tiklaf, al-ihsan, al-amanah, ashshiddiq, al-adl, al-khiyar, at-ta'wun, keamanan dan keselamatan, dan at-taradhin. Di dalam UUPK asas perlindungan konsumen dia- tur pada Pasal 2 yang menyebutkan bahwa "Perlindungan konsumen berasaskan man- faat, keadilan, keseimbangan, keamanan, dan keselamatan konsumen, serta kepastian hukum".

Asas pokok atau pondasi dari seluruh kegiatan bisnis di dalam hukum Islam ditempatkan pada asas tertinggi, yaitu tauhid (mengesakan Allah SWT). (Dari asas ini kemudian lahir asas istikhlaf, yang me- nyatakan bahwa apa yang dimiliki oleh ma- nusia hakekatnya adalah titipan dari Allah SWT, manusia hanyalah sebagai pemegang amanah yang diberikan kepadanya. Dari asas tauhid juga melahirkan asas al-ihsan (benevolence), artinya melaksanakan per- buatan baik yang dapat memberikan ke- manfaatan kepada orang lain tanpa ada kewajiban tertentu yang mengharuskannya untuk melaksanakan perbuatan tersebut.

Dari ketiga asas di atas melahirkan asas al-amanah, ash-shiddiq, al-adl, alkhiyar, at-ta'wun, keamanan dan keselamatan, dan at-taradhin. Menurut asas alamanah setiap pelaku usaha adalah pengemban ama- nah untuk masa depan dunia dengan segala isinya (kholifah fi al-ardhi), oleh karena itu apapun yang dilakukannya akan dipertanggung jawabkan di hadapan manusia dan di hadapan sang pencipta (Allah SWT).( Sidabolok. 2010:48)

Ash-shiddiq adalah prilaku jujur, yang paling utama di dalam berbisnis adalah kejujuran. Al-adl adalah keadilan, keseimbangan, dan kesetaraan yang menggambarkan dimensi horizontal dan berhubungan dengan harmonisasi segala sesuatu di alam semesta ini. Al khiyar adalah hak untuk memilih dalam transaksi bisnis, hukum Islam mene- tapkan asas ini untuk menjaga terjadinya perselisihan antara pelaku usaha dengan konsumen. Ta'awun adalah tolong menolong, ta'awun memiliki arti yang sangat penting dalam kehidupan ini karena tidak ada satupun 
manusia yang tidak membu- tuhkan bantuan dari orang lain, sehingga tolong menolong antara sesama manusia merupakan keniscayaan, terutama dalam upaya meningkatkan kebaikan dan ketak- waaan kepada Allah SWT. Untuk itu, dalam hubungannya dengan transaksi antara kon- sumen dan produsen asas ini harus dijiwai oleh kedua belah pihak.

Asas Keamanan dan Keselamatan, dalam hukum Islam ada lima hal yang wajib di- jaga dan dipelihara (al-dharuriyyat al-khamsah), yaitu: (1) memeliharaan agama (hifdh al-din), (2) memelihara jiwa (hifdh al-nafs), (3) memelihara akal (hifdh al-aql), (4) memelihara keturunan (hifdh nasl), dan memelihara harta (hifdh al-maal). Asas at-taradhi (kerelaan). Salah satu syarat sahnya jual beli di dalam Islam adalah aqad atau transaksi. Aqad atau transaksi tidak pernah akan terjadi kecuali dengan shighat (ijab-qabul), yaitu segala hal yang menun- jukkan kerelaan atau kesepakatan kedua belah pihak (penjual dan pembeli).

Dari pembahasan di atas dapat diurai- kan bahwa asas-asas perlindungan konsumen dalam hukum Islam lebih luas dan konprehensif dari pada asas-asas perlindun- gan konsumen di dalam UUPK, yang mana di dalam hukum Islam tidak hanya men- gatur hubungan horizontal yaitu hubun- gan pelaku usaha dengan konsumen atau pelaku usaha dengan pelaku usaha lainnya, (hablum minannas), tetapi hukum Islam juga mengatur hubungan manusia secara vertikal (hablum minallah) yaitu hubun- gan antara manusia (pelaku usaha dan kon- sumen) dengan Allah SWT selaku pemilik alam semesta ini beserta isinya. Sedangkan UUPK hanya mengatur hubungan antara pelaku usaha dengan konsumen saja sebagaimana diatur pada Pasal 2.

\section{2). Tujuan Perlindungan Konsumen Dalam Hukum Islam Dan UUPK}

Tujuan perlindungan konsumen dalam hukum Islam adalah untuk mewujudkan mashlahah (kemaslahatan) bagi umat ma- nusia. Sedangkan tujuan perlindungan konsumen di dalam UUPK sebagaimana dimaksud dalam Pasal 3 adalah :

a) Meningkatkan kesadaran, kemam- puan dan kemandirian konsumen untuk melindungi diri;

b) Mengangkat harkat dan martabat konsumen dengan cara menghindar- kannya dari akses negatif, pemakaian barang dan/atau jasa;

c) Meningkatkan pemberdayaan kon- sumen dalam memilih, menentukan dan menuntut hak-haknya sebagai konsumen;

d) Menciptakan sistem perlindungan konsumen yang mengandung unsur kepastian hukum dan keterbukaan in- formasi, serta akses untuk mendapat- kan informasi;

e) Menumbuhkan kesadaran pelaku usaha mengenai pentingnya perlind- ungan konsumen sehingga tumbuh si- kap yang jujur dan bertanggung jawab dalam berusaha;

f) Meningkatkan kualitas barang dan/ atau jasa yang menjamin kelangsungan usaha produk barang dan tau jasa, kesehatan, kenyamanan, ke- amanan, dan keselamatan konsumen.

Jika memperhatikan tujuan perlindun- gan konsumen yang terdapat pada Pasal 3 UUPK tersebut di atas sesuai dengan hu- kum Islam dan maqashid al-syari'ah (tujuan disyariatkannya hukum) yaitu untuk kemaslahatan bagi manusia.

\section{c. Hak dan Kewajiban Konsumen}

a. Hak-Hak Konsumen Dalam Hukum Islam Dan UUPK 
Menurut hukum Islam ada enam hak konsumen yang membutuhkan perhatian serius dari pelaku usaha, yaitu; (Muhamad, ddk.

1) Hak untuk mendapatkan informasi yang benar, jujur, adil, dan terhindar dari pemalsuan

2) Hak untuk mendapatkan keamanan produk dan lingkungan sehat

3) Hak untuk mendapatkan advokasi dan penyelesaian sengketa

4) Hak untuk mendapatkan perlindungan dari penyalahgunaan keadaan

5) Hak untuk mendapatkan ganti rugi akibat negatif dari suatu produk

6) Hak untuk memilih dan memperoleh nilai tukar yang wajar

Dalam Islam, kerugian atau bahaya fisik yang diderita oleh konsumen karena cacat produk atau penipuan adalah perbua- tan yang tidak dibenarkan, oleh karena itu pelaku usaha/produsen harus bertanggung jawab atas perbuatannya itu. Tanggung jawab jika dihubungkan dengan penyebab adanya ganti rugi (dhaman) dapat dibeda- kan menjadi lima, yaitu :

a) Ganti Rugi Karena Perusakan (Dha-man Itlaf)

b) Ganti Rugi Karena Transaksi (Dha- man 'Aqdin)

c) Ganti Rugi Karena Perbuatan (Dha- man Wadh'u Yadin)

d) Ganti Rugi Karena Penahanan (Dhaman al-Hailulah)

e) Ganti Rugi Karena Tipu daya (Dha- man al-Maghrur)

Dhaman Itlaf adalah ganti rugi akibat dari perusakan barang. Ganti rugi itlaf tidak hanya berhubungan dengan kerusakan harta benda saja, tetapi juga menyangkut jiwa dan anggota tubuh manusia. Dhaman 'aqdin adalah terjadinya suatu aqad atau transaksi sebagai penyebab adanya ganti rugi atau tanggung jawab. Ganti rugi wadh' $u$ yadin adalah ganti rugi akibat dari keru- sakan barang yang masih berada di tangan penjual apabila barang belum diserahkan dalam sebuah aqad yang sah dan ganti rugi karena perbuatan mengambil harta orang lain tanpa izin. Dhaman alhailulah adalah ganti rugi pada jasa penitipan barang (al- wadi) jika terjadi kerusakan atau hilang, baik kerusakan atau hilangnya itu dise- babkan karena kelalaian atau kesengajaan orang yang dititipi. Dhaman al-maghrur adalah ganti rugi akibat tipu daya. Dhaman al-maghrur sangat efektif diterapkan dalam perlindungan konsumen, karena segala bentuk perbuatan yang dapat merugikan orang lain pelakunya harus membayar ganti rugi sebagai akibat dari perbuatannya itu.

Salah satu hak konsumen dalam Islam adalah hak untuk memilih yang dikenal dengan istilah khiyar. Melalui hak khiyar ini, Islam memberikan ruang yang cukup luas bagi konsumen dan produsen untuk mempertahankan hak-hak mereka dalam perdagangan apakah melanjutkan aqad/ transaksi bisnis atau tidak. Para ulama' membagi hak khiyar menjadi tujuh macam yaitu : khiyar majlis, khiyar syarath, khiyar aibi, khiyar tadlis, khiyar ru'yah, khiyar al-ghabn al-fahisy (khiyar almurtarsil), dan khiyar ta'yin

Khiyar majlis, adalah hak untuk memil- ih melanjutkan atau membatalkan transaksi bisnis selama masih berada dalam satu tempat (majlis).( Abdurrahman:2001:41). Khiyar syarath adalah hak untuk memilih melanjutkan atau mem- batalkan transaksi bisnis sesuai dengan waktu yang disepakati atau syarat yeng telah ditetapkan bersama. Khiyar aibi adalah hak untuk membatalkan transaksi bisnis apabila obyek transaksi cacat sekalipun tidak ada perjanjian sebelumnya. Cacat yang dapat dijadikan alasan untuk mengembalikan ba- rang adalah cacat yang dapat menyebabkan turunnya harga. Khiyar tadlis terjadi jika penjual mengelabui pembeli. Dalam hal ini pembeli memiliki hak Khiyar selama tiga hari.(as sabatin. 2009: 312) 
Di dalam kitab Fiqh Empat Madzhab bagian muamalat Abdurrahman Al-Jaziri menyebut khiyar jenis ini dengan istilah "khiyar al-taghriri al-fi'liyy (khiyar karena tertipu oleh tindakan penjual). Khiyar ru'yah adalah hak pilih untuk melanjutkan atau membatalkan transaksi bisnis yang dilakukan terhadap suatu ob- jek yang belum dilihat pada saat transaksi dilaksanakan. (Hasan: 147)

Untuk sahnya transaksi jual beli/binis disyaratkan barang dan harganya diketahui dengan jelas oleh penjual dan pembeli. Maka tidak sah menjual atau membeli sesuatu yang tidak jelas, karena hal itu akan mendatangkan perselisihan. Khiyar al-ghabn al-fahisy (khiyar al-mur-tarsil) jika penjual dan pembeli merasa ditipu maka ia memiliki hak khiyar untuk menarik diri dari transaksi jual beli/bisnis dan membatalkan transaksi tersebut. Khiyar jenis ini pada suatu saat bisa menjadi hak penjual dan pada saat yang lain biasjuga menjadi hak pembeli. Khiyar Ta'yin adalah memberikan hak kepada pembeli untuk memilih barang yang dia inginkan dari sejumlah atau kumpulan barang yang dijual kendatipun barang tersebut berbeda harganya, sehingga konsumen dapat me- nentukan barang yang dia kehendaki (Hasan: 147).

Di dalam UUPK Pasal 4 diatur secara eksplisit delapan hak konsumen, yaitu :

1) Hak atas kenyamanan, keamanan, dan keselamatan dalam mengkonsumsi barang dan/atau jasa;

2) Hak untuk memilih barang dan/atau jasa serta mendapatkan barang dan/atau jasa tersebut sesuai dengan nilai tukar dan kondisi serta jaminan yang dijanjikan;

3) Hak atas informasi yang benar, jelas, dan jujur mengenai kondisi dan jaminan barang dan/atau jasa;

4) Hak untuk didengar pendapat dan kelu- hannya atas barang dan/atau jasa yang digunakan;

5) Hak untuk mendapatkan advokasi, per- lindungan, dan upaya penyelesaian seng- keta perlindungan konsumen secara patut;

6) Hak untuk mendapat pembinaan dan pen- didikan konsumen;

7) Hak unduk diperlakukan atau dilayani se- cara benar dan jujur serta tidak diskrimi- natif;

8) Hak untuk mendapatkan kompensasi, ganti rugi dan/atau penggantian, apabila barang dan/atau jasa yang diterima tidak sesuai dengan perjanjian atau tidak seb- agaimana mestinya;

9) Hak-hak yang diatur dalam ketentuan per- aturan perundang undangan lainnya. Di dalam penjelasan Pasal 4 Huruf g disebutkan bahwa "Hak untuk diperlakukan atau dilayani secara benar dan jujur serta tidak diskriminatif berdasarkan suku, agama, budaya, daerah, pendidikan, kaya, miskin, dan status sosial lainnya." Kaitannya dengan hak untuk mendapatkan kompensasi ganti rugi.

Pada Pasal 4 huruf g dipertegas lagi pada Pasal 19 yang menjelaskan "pelaku usa- ha bertanggung jawab memberikan ganti rugi atas kerusakan, pencemaran dan/atau kerugian konsumen akibat mengkonsumsi barang dan/atau jasa yang dihasilkan atau diperdagangkan.”

Memperhatikan hak-hak konsumen dalam hukum Islam dan UUPK memi- liki banyak kesamaan. Namun demikian ada juga perbedaannya, yaitu; hak untuk mendapatkan perlindungan dari peny- alahgunaan keadaan. Hak ini tidak diatur dalam UUPK. Selain itu, hak untuk diden-gar pendapat dan keluhannya atas barang dan/atau jasa yang digunakan, hak untuk mendapat pembinaan dan pendidikan konsumen, hak untuk diperlakukan atau dilayani secara benar dan jujur serta tidak diskriminatif. Hak-hak ini tidak diatur se- cara eksplisit dalam hukum Islam, tetapi 
jika dilihat dari maqashid al-syari'ah (tu- juan disyariatkannya hukum), maka semua hak konsumen yang diatur di dalam UUPK sesuai dengan hukum Islam, karena semua hak-hak itu prinsipnya untuk kebaikan konsumen.

\section{Simpulan}

Dalam Islam, kerugian atau bahaya fisik yang diderita oleh konsumen karena cacat produk atau penipuan adalah perbuatan yang tidak dibenarkan, oleh karena itu pelaku usaha/produsen harus bertanggung jawab atas perbuatannya itu. Tanggung jawab jika dihubungkan dengan penyebab adanya ganti rugi (dhaman) dapat dibeda- kan menjadi lima, yaitu :Ganti Rugi Karena Perusakan (Dha-man Itlaf), Ganti Rugi Karena Transaksi (Dha- man 'Aqdin), Ganti Rugi Karena Perbuatan (Dha- man Wadh'u Yadin), Ganti Rugi Karena Penahanan (Dhaman alHailulah), Ganti Rugi Karena Tipu daya (Dha- man al-Maghrur).

\section{Daftar Pustaka}

Al-Jaziri Abdurrahman, Fiqih Empat Mazdhab Bagian Muamalah II, terjemahan H. Chatibul Umam \& Abu Hurairah, Darul Ulum Press, 2001.

As-Sabatin ,Yusuf, Bisnis Islam Dan Kritik Atas Praktik Bisnis Ala Kapitalis, Bogor, Al-Azhar Press, 2009.

Aedi, Hasan, Teori dan Aplikasi Etika Bisnis Islam, Bandung, Alfabeta, 2011.

Badroen , Faisal et all, Etika bisnis Dalam Islam, Ja- karta, Kencana, 2007.

Hasan, M. Ali Berbagai Macam Transaksi dalam Is- lam (Fiqh Muamalat), Jakarta, PT Raja Grafindo Persa- da.

Muhammad \& Alimin, Etika \& Perlindungan Konsuman Dalam Ekonomi Islam, Yogyakarta,BPFE, 2004,

Sidabolok, Janus, Hukum Perlindungan Konsumen di Indonesia .Bandung: T. Citra Aditya Bakti, 2010.

Tim Redaksi Citra Umbara, Undang-Undang Tentang Perlindungan Konsumen: UU No. 8 Tahun 1999, Ps 1 Butir 1. Bandung: Citra Umbara, 2015.

Wuria, Eli, Hukum Perlindungan Konsumen, Yogyakarta: Graha Ilmu, 2015.

Yahya ,Mukhtar, dan Fatchurrahman, Dasar-dasar Pembinaan Hukum Fiqh Islam, Bandung, Alma'arif, 1986.

Qardhawi ,Yusuf, Norma Dan Etika Ekonomi Islam, Penerjemah Zainal Arifin dan Dahlia Husin, Ja- karta, Gema Insani Press, 1997. 